\title{
PENGARUH TINGKAT KEBISINGAN TERHADAP PENINGKATAN DENYUT NADI PADA OPERATOR LINI PRODUKSI (STUDI KASUS: PT XYZ)
}

\author{
Rama Dani Eka Putra ${ }^{1 *}$, Fuad Dwi Hanggara ${ }^{2}$ \\ ${ }^{1,2}$ Program Studi Teknik Industri, Fakultas Teknik, Universitas Universal \\ Komplek Maha Vihara Duta Maitreya, Bukit Beruntung, Sungai Panas, Batam, 29433 \\ *e-mail : ramadaniekaputra1727@gmail.com
}

\begin{abstract}
PT. XYZ is a company engaged in the processing of semi-finished rubber (crumb rubber) located in Pekanbaru City. Based on preliminary observations it is known that there are several production areas that are exposed to noise exceeding the set threshold, in addition to the perceived noise the operator is also still doing manual material handling with a very large product unit load. This is thought to be a decrease in work quality. Declining in work quality is usually caused by too much work that uses physical labor force. So this study aims to determine whether there is an influence of engine noise with physical workload felt by the operator and know the factors that affect the operator's pulse to noise in the production line of PT. XYZ The method used in this study is the physiology method and ANOVA test. Based on the results of the discussion there is an influence between the level of engine noise with the physical workload felt by the operator at PT. XYZ and the factors that affect the pulse of the operator are age, work experience and also the work load.
\end{abstract}

Keywords: Physical Workload, Physiological, Noise

\section{Pendahuluan}

Penurunan dalam kualitas kerja biasanya disebabkan karena terlalu banyaknya pekerja menggunakan kekuatan kerja fisik. Secara umum yang dimaksudkan dengan kerja fisik adalah kerja yang memerlukan kekuatan otot manusia sebagai sumber tenaganya. Kerja yang memerlukan energi fisik sering kali disebut sebagai "manual operation" di mana kinerja operator sepenuhnya akan tergantung pada manusia yang berfungsi sebagai sumber tenaga atau pun pengendali kerja (Wignjosoebroto, 2008 dalam Salsia et al., 2018). Hal lain yang dapat menurunkan kualitas kerja adalah kebisingan. Kebisingan adalah semua bunyi yang mengalihkan perhatian, menggangu atau berbahaya bagi kegiatan sehari-hari (Setiawan, 2010) Kebisingan dari mesin yang sedang digunakan juga dapat menjadi faktor pengaruh beban kerja karyawan, berdasarkan pengukuran kebisingan suara yang ada di 4 stasiun pabrik PT. XYZ, 3 stasiun mempunyai nilai kebisingan yang berada di atas ambang batas yang telah ditentukan. Menurut (Huldani, 2012) yang menyimpulkan hasil penelitiannya bahwa terdapat peningkatan tekanan darah pekerja pada intensitas kebisingan diatas nilai ambang batas. (Wardani, Kedokteran, \& Sebelas, 2013) dalam hasil penelitiannya menunjukkan bahwa ada hubungan antara tekanan darah karyawan dengan intensitas kebisingan. Peningkatan tekanan sistole dengan nilai diatas $85 \mathrm{dBA}$ mempunyai kemungkinan 0.2 kali untuk meningkatkan tekanan sistole responden. (Sandi I, 2013) dalam penelitiannya menyebutkan bahwa rata-rata denyut nadi normal seseorang adalah 60-80 per menit, bila denyut nadi semakin tinggi akan menyebabkan kekuatan fisik yang lebih banyak lagi dalam bekerja.

Berdasarkan Keputusan Menteri Kesehatan RI No. 261 Tahun 1998, area kerja yang menggunakan mesin mengeluarkan suara melebihi $85 \mathrm{~dB}$ dalam satu hari dibatasi waktu bekerja selama 8 jam. Pekerjaan yang melebihi batas waktu yang telah ditentukan akan menimbulkan keluhan pada operator. Keluhan yang dirasakan dari operator yaitu menurunya pendengaran dan konsentrasi pekerja. Berdasarkan observasi awal didapati suatu fakta bahwa operator masih mengangkut lempengan karet menggunakan troli manual dengan beban $500 \mathrm{~kg}$. Hal ini tentunya sangat menyulitkan operator dalam memindahkannya dari area penggilingan.

Berdasarkan latar belakang yang telah diuraikan maka ditetapkan tujuan dari penelitian ini adalah sebagai berikut:

1. Untuk mengetahui apakah ada pengaruh kebisingan mesin dengan beban kerja fisik yang dirasakan oleh operator PT. XYZ 
2. Untuk Mengetahui faktor apa saja yang mempengaruhi denyut nadi operator terhadap kebisingan di lini produksi PT. XYZ

\section{Landasan Teori}

\subsection{Jenis Beban Kerja}

Setiap pekerjaan apapun pekerjaannya tersebut memerlukan kekuatan otot atau pemikiran, adalah merupakan beban bagi pelakunya. Beban ini dapat berupa beban fisik, beban mental ataupun beban sosial sesuai dengan jenis pekerjaan si pelaku. Masing-masing orang memiliki kemampuan yang berbeda dalam hubungannya dengan beban kerja. Ada orang yang lebih cocok untuk menanggung beban kerja fisik, tetapi ada orang lain lebih cocok melakukan pekerjaan yang lebih banyak pada beban mental atau sosial (Mutia, 2016).

\subsection{Faktor yang Mempengaruhi Beban Kerja}

Menurut Tarwaka, faktor yang mempengaruhi beban kerja adalah sebagai berikut (Mutia, 2016):

\section{Faktor Eksternal}

Faktor eksternal beban kerja adalah beban kerja yang berasal dari luar tubuh pekerja. Aspek beban kerja eksternal serig disebut stresor. Yang termasuk beban kerja eksternal adalah:

a. Tugas-tugas (task). Tugas ada yang besifat fisik seperti, tata ruang kerja, stasiun kerja, alat dan sarana kerja, kondisi kerja, sikap kerja dan alat bantu kerja. Tugas juga ada yang bersifat mental seperti, kompleksitas pekerjaan dan tanggung jawab pekerjaan.

b. Organisasi kerja. Organisasi kerja yang mempengaruhi beban kerja misalnya, lamanya waktu kerja, waktu istirahat, kerja bergilir, sistem pengupahan, kerja malam, musik kerja, tugas dan wewenang.

c. Lingkungan kerja. Lingkungan kerja yang dapat mempengaruhi beban kerja adalah yang temasuk dalam beban tambahan akibat lingkungan kerja. Misalanya saja lingkungan kerja fisik (penerangan, kebisingan, getaran mekanis), lingkungan kerja kimiawi (debu, gas pencemar udara), lingkungan kerja biologis (bakteri, virus dan parasit) dan lingkungan kerja psikologis (penempatan tenaga kerja).

2. Faktor Internal

Faktor internal beban kerja adalah faktor yang berasal dari dalam tubuh itu sendiri sebagai akibat adanya reaksi dari beban kerja eksternal. Reaksi tersebut dikenal dengan strsin. Secara ringkas faktor internal meliputi.

a. Faktor somatis, yaitu jenis kelamin, umur, ukuran tubuh, kondisi kesehatan, status gizi.

b. Faktor psikis, yaitu motivasi, persepsi, kepercayaan, keinginan, kepuasan dan lainlain.

\subsection{Kebisingan}

Menurut Sv Azokolay (1979) dalam (Setiawan, 2010) kebisingan didefinisikan sebagai getaran-getaran yang tidak biasa. Faktorfaktor yang mempengaruhinya antara lain adalah pola intensitas, frekuensi dan pembangkitan (kontinu versus acak).

\section{Metode Penelitian}

Penelitian ini dilaksanakan di PT. XYZ Pota Pekanbaru yang bergerak pada proses pengolahan crumb rubber. Area yang menjadi studi kasus penelitian adalah area penghancur karet, pengolahaan basah, pengolahan kering dan packing. Data kebisingan diambil dengan menggunakan aplikasi Level Meter Apps. Setelah dilakukan pengambilan data kebisingan kemudian dilakukan pengambilan data besaran denyut jantung operator sebanyak 80 orang yang berada pada area studi kasus dengan menggunakan Pulse Meter (Oxy 3). Penelitian ini merupakan jenis penelitian deskriptif kuantitatif yang menjelaskan secara jelas hasil dari pengukuran kebisingan dan beban kerja yang dirasakan oleh operator. Adapun langkah-langkah dalam penelitian ini adalah sebagai berikut:

1. Uji ANOVA

Uji ANOVA merupakan sebuah metode yang digunakan untuk menguji perbedaan ratarata lebih dari dua sampel. Tujuan uji ANOVA adalah menguji kemampuan generalisasi atau signifikansi hasil penelitian. Artinya, jika terbukti berbeda berarti kedua sampel tersebut dapat digeneralisasi (data sampel dapat dianggap mewakili populasi). Pada penelitian ini yang menjadi variabel dependent adalah variabel denyut nadi dan yang menjadi variabel independent adalah variabel tingkat kebisingan. Adapun hipotesis pada penelitian ini adalah sebagai berikut:

Dimana:

$\mathrm{H}_{0}$ : Tidak ada pengaruh tingkat kebisingan terhadap denyut nadi operator

$\mathrm{H}_{1}$ : Ada pengaruh tingkat kebisingan terhadap denyut nadi operator

\section{Uji Regresi}

Uji regresi dilakukan untuk mengetahui pola data dan bentuk pengaruh dari sebuah variabel. Analisis regresi digunakan untuk mengetahui besarnya pengaruh satu variabel bebas atau lebih terhadap satu variabel tidak bebas. Data yang di analisis dengan regresi merupakan data kuantitatif yang memiliki skala pengukuran adapun rumus regresi yang digunakan adalah 
sebagai berikut (Abraham, Walpole, \& Myers, 2012):

$\mathrm{Y}=a=\frac{\sum Y-b\left(\sum X\right)}{n}+{ }_{b}=\frac{n\left(\sum X Y\right)-\left(\sum X\right)\left(\sum Y\right)}{n\left(\sum X^{2}\right)-\left(\sum X\right)^{2}}$

3. Grafik Perbandingan Antara Tingkat Kebisingan dengan Denyut Nadi

Pembuatan grafik ini dilakukan untuk melihat secara grafis gambaran antara tingkat kebisingan dengan tingkat denyut nadi. Selain itu pembuatan grafik ini bertujuan untuk membantu pembaca memahami hasil dari pengolahan data. Grafik yang terdapat pada pengolahan ini adalah denyut nadi dengan tingkat kebisingan di tiga area di PT. XYZ yang dijadikan objek pengukuran oleh peneliti.

4. Analisis Data Responden

Analisis data responden dilakukan untuk memberikan gambaran dan penjelasan yang akan disajikan dalam bentuk diagram batang untuk menentukan faktor-faktor apa saja yang menjadi pengaruh peningkatan denyut nadi yang terpapar oleh kebisingan yang melebihi nilai ambang batas.

5. Analisa Usulan Perbaikan

Analisa bertujuan untuk menganalisa hasil dari pengolahan data agar mendapatkan usulan perbaikan yang sesuai dengan permasalahan pada penelitian ini.

\section{Hasil dan Pembahasan}

Berdasarkan pengumpulan data awal diketahui bahwa rata-rata denyut nadi operator ketika sebelum dan sesudah bekerja yang terpapar kebisingan seperti yang terlihat pada tabel 1

Tabel 1. Rekapitulasi rata-rata denyut nadi operator sebelum dan sesudah bekerja yang terpapar kebisingan.

\begin{tabular}{lccc}
\hline \multicolumn{1}{c}{ Area } & \multicolumn{2}{c}{ Denyut Nadi } & Kebisingan \\
\cline { 2 - 3 } & $\begin{array}{l}\text { Sebelum } \\
\text { Bekerja }\end{array}$ & $\begin{array}{l}\text { Sesudah } \\
\text { Bekerja }\end{array}$ & \\
\hline Penghancur & 70,6 & 90,25 & $90 \mathrm{~dB}$ \\
$\begin{array}{l}\text { Pengolahan } \\
\text { Basah }\end{array}$ & 75,25 & 90,5 & $95 \mathrm{~dB}$ \\
$\begin{array}{l}\text { Pengolahan } \\
\text { Kering }\end{array}$ & 70,75 & 90 & $87 \mathrm{~dB}$ \\
Packing & 69,25 & 80,25 & $84 \mathrm{~dB}$ \\
\hline
\end{tabular}

\section{1) Uji ANOVA (Analyze of Variance)}

Uji ANOVA dilakukan untuk mengetahui pengaruh denyut nadi operator dengan tingkat kebisingan yang terjadi di PT. XYZ. Dalam hal ini area penghancur dengan kebisingan $90 \mathrm{~dB}$, area pengolahan basah $95 \mathrm{~dB}$, area pengolahan kering $87 \mathrm{~dB}$ dan area packing $84 \mathrm{~dB}$. Bahwa nilai f tabel pegolahan data yakni sebesar 3.96, nilai ini didapatkan dengan bantuan Microsoft Excel 2013 dengan memasukan nilai tingkat kebisingan dan nilai derajat kebebasan data denyut nadi dengan tingkat kebisingan yang diolah. Hasil perhitungan Analyze of Variance denyut nadi terhadap tingkat kebisingan dengan menggunakan software SPSS dapat dilihat pada Tabel 2. Data yang di ujikan adalah dari masingmasing operator pada area kerjanya dengan tingkat kebisingan pada area kerja masingmasing.

Tabel 2. Output SPSS 17.0 Uji ANOVA Kebisingan terhadap Denyut Nadi Karyawan

\begin{tabular}{|c|c|c|c|c|c|}
\hline & $\begin{array}{l}\text { Sum of } \\
\text { Squares }\end{array}$ & $d f$ & $\begin{array}{l}\text { Mean } \\
\text { Squares }\end{array}$ & $F$ & Sig \\
\hline $\begin{array}{l}\text { Between } \\
\text { Groups }\end{array}$ & 819.394 & 1 & 819.394 & 63.683 & .000 \\
\hline $\begin{array}{l}\text { Within } \\
\text { Groups }\end{array}$ & 1003.606 & 78 & 12.867 & & \\
\hline Total & 1823.000 & 79 & & & \\
\hline
\end{tabular}

Sumber: Pengolahan SPSS 17.0, 2016

Berdasarkan pengolahan Software SPSS 17.0 didapatkan hasil Between Groups sebesar 819.94, untuk nilai Within Groups 1003.606 dan total sebesar 1823.000 nilai degree of fredoom untuk nilai between groups sebesar 1, untuk nilai Within Groups 78 dan totalnya 79. Nilai mean square untuk between groups sebesar 819,394 dan untuk nilai Within Groups 12.867. Pengolahan ANOVA data denyut nadi dengan tingkat kebisingan di PT. XYZ dengan menggunakan software SPSS 17.0 mendapatkana nilai f hitung sebesar 63.683. Dari hasil uji ANOVA maka didapat $f$ Hitung $>f$ tabel yaitu $63.683>3.96$ yang kemudian di analisa pada bab selanjutnya.

2) Uji Regresi

Menentukan hubungan antara denyut jantung dengan tingkat kebisingan dapat dilakukan dengan menggunakan bantuan software SPSS 17.0 berdasarkan data yang terkumpul, diketahui bahwa jumlah data adalah 80. Berdasarkan tabel 4.7 dapat dilihat bahwa nilai $\mathrm{T}$ tabel pada pengolahan data yakni sebesar 1.96. Nilai ini didapatkan dengan bantuan Microsoft Excel 2013 dengan memasukan nilai tingkat kepercayaan dan nilai derajat kebebasan data denyut nadi dengan tingkat kebisingan yang diolah. Hasil perhitungan Uji Regresi denyut nadi terhadap tingakt kebisingan dengan 
menggunakan software SPSS dapat dilihat pada Tabel 3.

Tabel 3. Nilai Uji Regresi Menggunakan Software SPSS 17.0

\begin{tabular}{|c|c|c|c|c|c|}
\hline \multirow[t]{2}{*}{ Model } & \multicolumn{2}{|c|}{$\begin{array}{l}\text { Unstandarilized } \\
\text { Coefficients }\end{array}$} & \multirow{2}{*}{$\begin{array}{c}\begin{array}{l}\text { Standarilized } \\
\text { Coefficients }\end{array} \\
\text { Beta }\end{array}$} & \multirow[t]{2}{*}{$t$} & \multirow[t]{2}{*}{ Sig. } \\
\hline & $B$ & $\begin{array}{l}\text { Std } \\
\text { Error }\end{array}$ & & & \\
\hline 1 (Constant) & 17.629 & 8.796 & .870 & 2.004 & .049 \\
\hline Kebisingan & .786 & .099 & & 7.960 & .000 \\
\hline
\end{tabular}

Dari pengolahan data menggunakan SPSS 17.0 maka didapatkan grafik penyebaran datanya. Grafik ini berfungsi untuk melihat penyebaran data yang ada pengolahan data penelitian ini.

Normal P.P Plot of Regression Standardized Residual

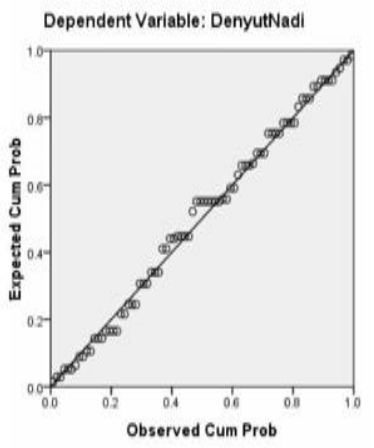

Gambar 1. Grafik Uji Regresi Menggunakan SPSS 17.0

3) Grafik Perbandingan antara Denyut Nadi terhadap Tingkat Kebisingan

Grafik digunakan untuk melihat secara visual perbandingan dan pengaruh denyut nadi dengan tingkat kebisingan yang terdapat di beberapa area PT. XYZ. Grafik menggambarkan perbandingan satu area dengan area yang lainnya untuk melihat operator mana saja yang melebihi denyut nadi yang melebihi batas standar yang kemudian nantinya akan di analisa pada bab selanjutnya.

a. Grafik Perbandingan Denyut Nadi dengan Tingkat Kebisingan di area packing dengan area penghancur

Grafik perbandingan denyut nadi dengan tingkat kebisingan di area packing dengan area penghancur dapat dilihat pada Gambar 2, dimana akan menunjukan data denyut nadi yang berada diatas ambang batas sebesar $85 \mathrm{~dB}$. Dimana kebisingan pada area penghancur sebesar $90 \mathrm{~dB}$ dan Packing $84 \mathrm{~dB}$.

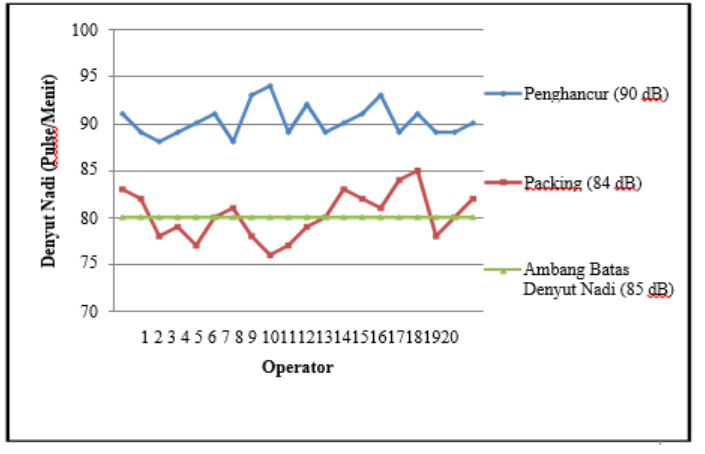

Gambar 2. Grafik Perbandingan Denyut Nadi dengan Tingkat Kebisingan di area packing dengan area Pengolahan Kering

Grafik perbandingan di atas berguna untuk menganalisa pada operator mana saja yang mempunyai denyut nadi di atas ambang batas yang telah ditentukan oleh pemerintah diantara kedua area produksi, yaitu pada area penghancur dan area packing sehingga dapat dilihat tingkat kelelahan dan banyaknya operator yang melebihi ambang batas denyut nadi.

b. Grafik Perbandingan Denyut Nadi dengan Tingkat Kebisingan di area Packing dengan area Pengolahan Basah

Grafik perbandingan denyut nadi dengan tingkat kebisingan di area packing dengan area penghancur dapat dilihat pada Gambar 3, dimana menunjukan data denyut nadi yang berada diatas ambang batas sebesar $85 \mathrm{~dB}$. Dimana kebisingan pada area pengolahan basah sebesar $95 \mathrm{~dB}$ dan Packing $84 \mathrm{~dB}$.

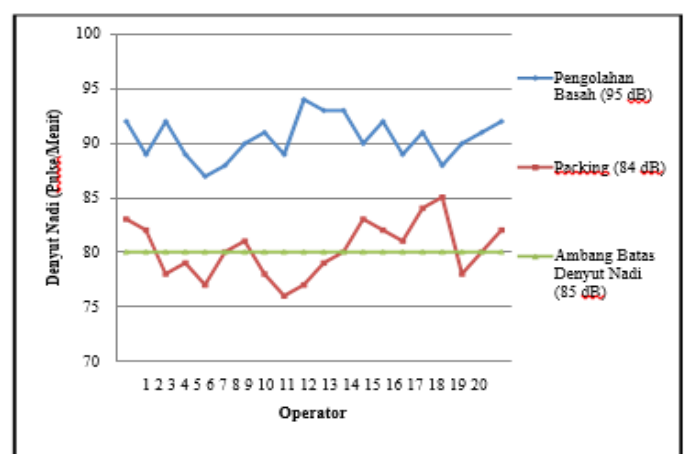

Gambar 3. Grafik Perbandingan Denyut Nadi dengan Tingkat Kebisingan di area packing dengan area Pengolahan Basah

Grafik perbandingan di atas berguna untuk menganalisa pada operator mana saja yang mempunyai denyut nadi di atas ambang batas yang telah ditentukan oleh pemerintah diantara kedua area produksi, yaitu pada area pengolahan basah dan area packing sehingga dapat dilihat tingkat kelelahan dan banyaknya operator yang melebihi ambang batas denyut nadi 
c. Grafik Perbandingan Denyut Nadi dengan Tingkat Kebisingan di area packing dengan area Pengolahan Kering

Grafik perbandingan denyut nadi dengan tingkat kebisingan di area packing dengan area pengolahan kering dapat dilihat pada Gambar 4 dimana akan menunjukan data denyut nadi yang berada diatas ambang batas sebesar $85 \mathrm{~dB}$. Dimana kebisingan pada area pengolahan kering sebesar $87 \mathrm{~dB}$ dan packing $84 \mathrm{~dB}$

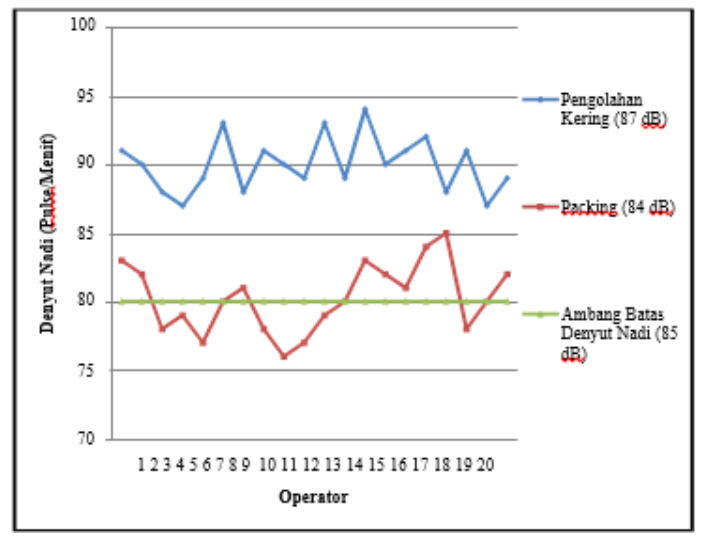

Gambar 4. Grafik Perbandingan Denyut Nadi dengan Tingkat Kebisingan di area packing dengan area Pengolahan Kering

Grafik perbandingan di atas berguna untuk menganalisa pada operator mana saja yang mempunyai denyut nadi di atas ambang batas yang telah ditentukan oleh pemerintah diantara kedua area produksi, yaitu pada area penghancur dan area packing sehingga dapat dilihat tingkat kelelahan dan banyaknya operator yang melebihi ambang batas denyut nadi.

d. Grafik Perbandingan Denyut Nadi dengan Tingkat Kebisingan di Seluruh Area Produksi

Grafik perbandingan denyut nadi dengan tingkat kebisingan di area packing dengan area penghancur dapat dilihat pada Gambar 5 dimana akan menunjukan data denyut nadi yang berada diatas ambang batas sebesar $85 \mathrm{~dB}$. Dimana kebisingan pada area penghancur sebesar $90 \mathrm{~dB}$ dan packing $84 \mathrm{~dB}$.

Grafik perbandingan pada gambar 5 berguna untuk menganalisa pada operator mana saja yang mempunyai denyut nadi di atas ambang batas yang telah ditentukan oleh pemerintah diantara kedua area produksi, yaitu pada area penghancur dan area packing sehingga dapat dilihat tingkat kelelahan dan banyaknya operator yang melebihi ambang batas denyut nadi.

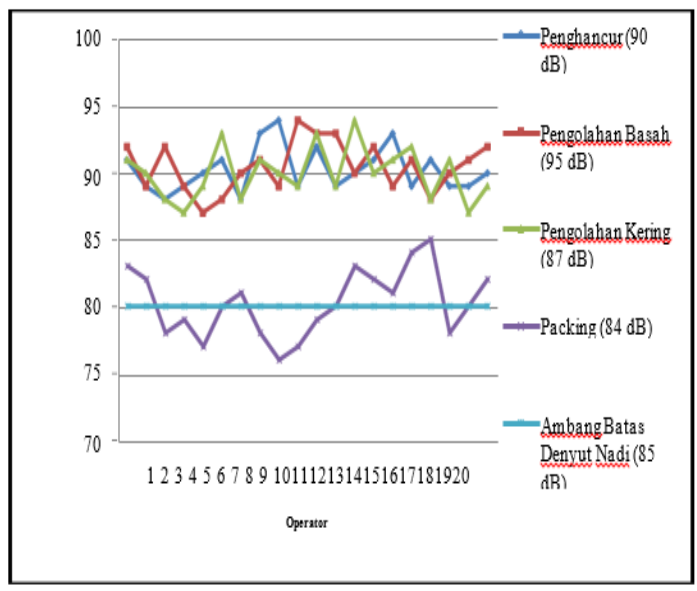

Gambar 5. Grafik Perbandingan Denyut Nadi dengan Tingkat Kebisingan di Seluruh Area Produksi

4) Analisa Data Responden

Berdasarkan grafik denyut nadi antar area produksi, diketahui bahwa interval dari denyut nadi, pengalaman kerja dan usia operator seperti pada Tabel 4.

Tabel 4. Klasifikasi data responden

\begin{tabular}{ccccc}
\hline No & $\begin{array}{c}\text { Jumlah } \\
\text { Operator }\end{array}$ & $\begin{array}{c}\text { Interval } \\
\text { Denyut } \\
\text { Nadi }\end{array}$ & $\begin{array}{c}\text { Pengalaman } \\
\text { Kerja }\end{array}$ & $\begin{array}{c}\text { Interval } \\
\text { Umur }\end{array}$ \\
\hline 1 & 7 & $77-79$ & 1 Tahun & $31-34$ \\
2 & 8 & $80-82$ & 2 Tahun & $35-38$ \\
3 & 5 & $83-85$ & $>5$ Tahun & $47-50$ \\
4 & 10 & $86-88$ & 3 Tahun & $39-42$ \\
5 & 15 & $89-91$ & 4 Tahun & $43-46$ \\
6 & 35 & $92-9 \underline{4}$ & $<1$ Tahun & $27-30$ \\
\hline
\end{tabular}

Berdasarkan Tabel 4 diketahui bahwa sebanyak 35 operator yang bekerja dengan paparan kebisingan diatas nilai ambang batas bahwa memang memiliki rentang denyut nadi yang tinggi Antara 92-94. Hal ini juga dipengaruhi berdasarkan pengalaman kerja yang dialami oleh operator dan usia yang masih muda.

5) Analisa Usulan Perbaikan

Berdasarkan perbandingan dari masingmasing operator yang terpapar kebisingan yang melebihi nilai ambang batas pada masing-masing area yang berbeda didapatkan bahwa beberapa usulan perbaikan untuk kedepannya, diantaranya adalah sebagai berikut:

a. Operator diberikan alat pelindung diri berupa ear plug, karena operator yang terpapar kebisingan menurut (Hermawati, 2006) menemukan hasil penelitian bahwa kebisingan yang melebihi nilai ambang batas 
(NAB) dapat menyebabkan berbagai gangguan terhadap kesehatan karyawan seperti gangguan peningkatan tekanan darah dan denyut jantung. Hal ini tentunya bukanlah sebuah hal yang baik untuk perusahaan.

b. Mesin yang mengalami kebisingan lebih dari nilai ambang batas sebaiknya dilakukan perawatan kembali karena sudah lamanya tidak melakukan perawatan, karena menurut (Suma'mur, 2009) kebisingan tidak hanya dapat menyebabkan gangguan pendengaran tetapi juga dapat menimbulkan peningkatan nadi kerja dan peningkatan tekanan darah.

c. Dilakukan pengecekan kesehatan rutin terhadap operator. Untuk menjamin kesehatan operator terkhusus pada bagian indera pendengaran.

\section{Kesimpulan}

Sesuai dengan tujuan yang telah ditetapkan, setelah melakukan pengolahan dan analisa data, maka didapat kesimpulan sebagai berikut:

1. Terdapat pengaruh antara tingkat kebisingan mesin dengan beban kerja fisik yang dirasakan oleh operator pada lini produksi di PT. XYZ. Hal ini dapat dilihat pada nilai $\mathrm{f}$ hitung sebesar 63.683. Dari hasil uji ANOVA maka didapat $f$ Hitung $>f$ tabel yaitu $63.683>3.96$, sehingga $\mathrm{H}_{0}$ diterima.

2. Berdasarkan analisa data responden yang telah terpapar kebisingan diatas nilai ambang batas didapati bahwa, faktor-faktor yang mempengaruhi denyut nadi operator terhadap tingkat kebisingan PT. XYZ adalah umur dan kebiasaan dari operator tersebut. Rata-rata operator yang sudah berumur tua dan sudah lama bekerja dengan intensitas kebisingan yang tinggi tidak mengalami peningkatan denyut nadi yang signifikan, begitu juga sebaliknya, operator yang masih muda dan masih baru dalam bekerja di intensitas kebisingan tinggi mengalami peningkatan denyut nadi yang sangat signifikan.

\section{Daftar Referensi}

Abraham, V. M., Walpole, R. E., \& Myers, R. H. (1979). Probability and Statistics for Engineers and Scientists. The Mathematical Gazette, 63(424),

141. https://doi.org/10.2307/3616039

Hermawati, E. (2006). Perbedaan Tekanan Darah Tenaga Kerja Pada Intensitas Kebisingan Yang Berbeda di PT Purinusa Eka Persada Semarang. 70.

Huldani. (2012). Kebisingan Memengaruhi Tekanan Darah PLTD Trisakti, Banjaramasin. Banjarmasin, 39(11), 813-
816.

Mutia, M. (2016). Pengukuran Beban Kerja Fisiologis dan Psikologis pada Operator Pemetikan Teh dan Operator Produksi Teh Hijau di PTMitra Kerinci. Jurnal Optimasi Sistem Industri, 13(1), 503. https://doi.org/10.25077/josi.v13.n1.p503517.2014

Salsia, K., Safitri, D. M., Anggraini, R. D., Industri, J. T., Industri, F. T., \& Trisakti, U. (2018). Intervensi Ergonomi Untuk Menurunkan Beban Kerja Pada Operator Lantai Produksi Bisnis Unit South Copper Rod. Jurnal Teknik Industri, 8(1), 34-42.

Sandi I. (2013). Summary for Policymakers. In Intergovernmental Panel on Climate Change (Ed.), Climate Change 2013 - The Physical Science Basis (Vol. 1, pp. 1-30). https://doi.org/10.1017/CBO978110741532 4.004

Setiawan, M. F. (2010). Tingkat Kebisingan Pada Perumahan Di Perkotaan. Jurnal Teknik Sipil Dan Perencanaan, 12(2), 191-201.

Suma'mur, P. . (2009). Higiene Perusahaan dan Keselamatan Kerja (Hiperkes). Jakarta: Cv.Agung Seto.

Wardani, K. L., Kedokteran, F., \& Sebelas, U. (2013). Hubungan antara paparan kebisingan dengan peningkatan tekanan darah tenaga kerja di pt mutu gading tekstil karanganyar. 